\title{
MENGUNGKAP PRAKTIK AKUNTABILITAS DALAM ORGANISASI GEREJA TORAJA JEMAAT TALLUNGLIPU
}

\author{
Vheny Manguma, Fransiskus Randa, Carolus Askikarno Palalangan \\ Program Studi Akuntansi, Fakultas Ekonomi dan Bisnis \\ Universitas Kristen Indonesia Paulus \\ vheny.manguma@yahoo.co.id
}

\begin{abstract}
ABSTRAK
Mengungkapkan Praktik Akuntabilitas dalam Organisasi Gereja Toraja Jemaat Tallunglipu. Penelitian ini bertujuan untuk memaknai praktik akuntabilitas dalam organisasi Gereja Toraja Jemaat Tallunglipu. Penelitian ini adalah penelitian deskriptif dengan menggunakan pendekatan kualitatif. Data diperoleh dengan melakukan observasi awal, wawancara, dan dokumentasi. Metode analisis data yang digunakan adalah reduksi data, penyajian data dan penarikan kesimpulan. Hasil penelitian menunjukkan bahwa, ada 3 akuntabilitas yang dimaknai dalam Gereja Toraja Jemaat Tallunglipu yaitu pertama akuntabilitas keuangan ysng dimaknai dalam bentuk pertanggungjawaban pihak Gereja kepada jemaatnya dengan pencatatan laporan keuangan yang transparan melalui warta jemaat dan yang kedua adalah akuntabilitas transendental atau pertanggungjawaban kerohanian yang dimaknai dalam bentuk kegiatan/aktivitas yang dilakukan oleh pihak Gereja dalam memenuhi tugas pelayanannya salah satunya untuk melayani sesama dan yang ketiga yaitu akuntabilitas horizontal yang dimaknai sebagai bentuk pertanggungjawaban pihak Gereja yang luar biasa kepada jemaatnya dalam bentuk diakonia.
\end{abstract}

Kata kunci : akuntabilitas keuangan, akuntabilitas transendental, akuntabilitas horizontal

\begin{abstract}
The Disclosure of Accountability Practise in Toraja Jemaat Tallunglipu Church. This study aims to interpret the practice of accountability in the organization of the Toraja Church of Tallunglipu Church. This research is a descriptive study using a qualitative approach. Data is obtained by conducting initial observations, interviews, and documentation. Data analysis methods used are data reduction, data presentation and conclusion drawing. The results showed that there were 3 accountability interpreted in the Toraja Church of Tallunglipu Church, namely financial accountability which was interpreted in the form of the Church's accountability to the congregation by recording transparent financial statements through the congregation's message and the second was transcendental accountability or spiritual responsibility which was interpreted in the form One of the activities / activities carried out by the Church in fulfilling its service duties is to serve others and the third is horizontal accountability, which is interpreted as a form of extraordinary Church accountability to the congregation in the form of diaconas.
\end{abstract}

Keywords: financial accountability, transcendental accountability, horizontal accountability 


\section{PENDAHULUAN}

Akuntabilitas adalah perwujudan pertanggungjawaban seseorang atau unit organisasi dalam mengelola sumber daya yang telah diberikan dan dikuasai dalam rangka pencapaian tujuan melalui suatu media berupa laporan akuntabilitas kinerja secara periodik (Jasmin dan Luther, 2010). Menurut (Randa, 2011), akuntabilitas bagi setiap organisasi baik organisasi privat maupun organisasi publik non pemerintah termasuk organisasi Gereja sangat dibutuhkan karena setiap organisasi mempunyai keterkaitan dengan pihak internal dan eksternal organisasi. Gereja termasuk dalam organisasi nirlaba yang merupakan suatu organisasi yang terbilang unik karena mampu beroperasi dan bahkan bertumbuh tanpa mengandalkan profit melainkan hanya dari persembahan jemaat yang diterima. Untuk itu penerimaan yang dilakukan di Gereja juga harus disertai dengan pertanggungjawaban pengelolahan keuangan karena tanpa adanya pertanggungjawaban dari pihak Gereja bisa menyebabkan permasalahan keuangan ataupun penyalahgunaan uang Gereja yang tidak banyak diketahui dan cenderung ditutup rapat-rapat agar tidak menjadi konsumsi publik. Dengan demikian menarik untuk dikaji guna mengungkap praktik akuntabilitas dalam Gereja Toraja Jemaat Tallunglipu.

Organisasi Gereja Toraja ini menganggap bahwa praktik akuntabilitas itu sebagai media penyampaian pengelolaan laporan keuangan yang dilakukan oleh pihak Gereja kepada jemaatnya melalui warta jemaat. Maka dari itu sikap jujur dan tanggung jawab yang harus di publikasikan dalam pengelolaan keuangan organisasi Gereja Toraja. Dalam penelitian ini objek yang akan diteliti adalah Gereja Toraja Jemaat Tallunglipu yang merupakan salah satu organisasi Gereja terbesar di Toraja Utara yang letaknya strategis, mudah dijangkau dan melakukan tiga kali ibadah (pagi, siang, sore) setiap Minggu. Penerimaan persembahan merupakan sumber penerimaan utama Gereja, hal ini sesuai dengan sifat gereja sebagai suatu organisasi nirlaba yang memang berfungsi sebagai tempat beramal bagi jemaat. Sumber pendapatan organisasi Gereja yaitu berasal dari uang persembahan jemaat baik itu melalui pundi persembahan maupun persembahan dari donator

Berdasarkan pemaparan di atas dari sekian banyaknya fenomena yang terjadi tersebut bahwa penting untuk melaksanakan praktik akuntabilitas dalam organisasi Gereja agar tanggung jawab Gereja dalam menciptakan laporan pertanggungjawaban keuangan bisa menjadi sarana yang konkret untuk mewujudkan transparansi dan akuntabilitas pengelolaan keuangan. Karena Gereja sebagai salah satu organisasi sektor publik maka dari itu para stakeholder cenderung untuk mengetahui pertanggungjawaban pengelolaan keuangan yang dilakukan oleh organisasi keagaamaan tersebut. Dengan adanya praktik akuntabilitas yang dilakukan dengan jelas dan terbuka akan memberikan keuntungan kepada organisasi Gereja dimana para stakeholder akan mempercayakan seluruhnya kepada pihak Gereja untuk mengatur segala pemasukan maupun pengeluaran keuangan yang ada.

\section{KAJIAN LITERATUR}

\section{Pengertian Akuntabilitas Keuangan}

Akuntabilitas keuangan adalah tanggungjawab yang harus dilakukan secara jujur dan benar kepada Tuhan maupun kepada warga jemaat. Seperti yang disampaikan Pdt.John Adi Palimbong, S.Th sebagai berikut :

" persembahan merupakan tanda ungkapan syukur warga jemaat kepada Tuhan karena itu sistem kejujuran, kebenaran, dan rasa penuh tanggungjawab dalam mengelolanya itu harus kepada Tuhan dan kemudian kepada warga jemaat untuk mempertanggungjawabkan keuangan tersebut secara tertulis."

\section{Bentuk Akuntabilitas Keuangan}


Dalam penelitian (Randa, 2011) mengenai dimensi akuntabilitas keuangan pada salah satu Gereja di Tana Toraja menemukan bahwa adanya kecenderungan pertanggungjawaban dan transparansi yang masih setengah hati pada masing-masing tingkatan organisasi keagamaan.

\section{Bentuk Akuntabilitas Horizontal}

Menurut (Mardiasmo, 2009) akuntabilitas dibagi menjadi 2 macam, yakni akuntabilitas vertikal dan akuntabilitas horizontal, dimana dalam lingkup Gereja akuntabilitas vertikal merupakan pertanggungjawaban atas pengelolaan dana kepada Tuhan dan akuntabilitas horizontal merupakan bentuk pertanggungjawaban pihak Gereja kepada jemaatnya.

\section{Bentuk Akuntabilitas Transendental}

Selain pentingnya pertanggungjawaban pelaporan keuangan sebagai bentuk rincian pendanaan dari pemasukan dan pengeluaran setiap program yang dilakukan tentunya juga ada pertanggungjawaban kerohanian(transendental) yang dilakukan oleh Gereja dalam pelayanannya kepada Tuhan. Pada aspek ini, akuntabilitas transendental bisa juga dikatakan sebagai akuntabilitas spiritual yang juga mempunyai makna bahwa individu atau organisasi mempunyai kesadaran untuk menyatakan akuntabilitas kepada yang sifatnya transenden yaitu Allah seperti yang dinyatakan oleh (Jacobs and Walker, 2000) dalam mengungkap model akuntabilitas organisasi Gereja IONA.

\section{METODE}

\section{Jenis Penelitian}

Jenis penelitian yang digunakan dalam penelitian ini adalah penelitian deskriptif yaitu mengungkap gambaran yang sebenarnya tentang praktik akuntabilitas dalam Gereja Toraja Jemaat Tallunglipu.

\section{Jenis dan Sumber Data}

Dalam penelitian ini, jenis data yang digunakan adalah data kualitatif, yaitu data yang diperoleh dari objek penelitian dalam bentuk informasi baik secara lisan maupun tulisan. Sumber data yang digunakan dalam penelitian ini adalah :

1. Data primer yang diperoleh secara langsung melalui wawancara dengan bagian Keuangan, Pendeta maupun Tata Usaha Gereja Toraja yang dapat memberikan informasi yang diperlukan dalam menyelesaikan skripsi ini.

2. Data sekunder, berupa laporan keuangan dan data-data yang didapatkan dari Gereja, Alkitab maupun dari jurnal ilmiah.

\section{Metode Pengumpulan Data}

Metode yang digunakan dalam penelitian ini adalah studi lapangan dengan metode Observasi,Wawancara dan Dokumentasi.

1. Pengamatan Langsung di lapangan (Observasi), Pengamatan terhadap suatu objek yang diteliti secara langsung untuk memperoleh data di Gereja Toraja Jemaat Tallunglipu

2. Teknik Wawancara, penulis melakukan tanya jawab secara langsung kepada bagian Keuangan, Pendeta maupun Tata Usaha Gereja Toraja yang dapat memberikan informasi yang berhubungan dengan topik dan masalah yang dibahas dalam penelitian ini.

3. Teknik Dokumentasi, yaitu dengan pencatatan dan pengkopian data-data sekunder yang mendukung penelitian.

\section{Metode Analisis Data}


Metode penelitian yang digunakan dalam penelitian ini adalah penelitian deskriptif dengan analisis kualitatif, yaitu dikemukakannya konsep teoritis dan gambaran mengenai objek penelitian dengan melihat praktik akuntabilitas pengelolaan keuangan yang dijalankan oleh Gereja sesuai dengan Tata Gereja Toraja agar pertanggungjawaban yang dilakukan mendapat kepercayaan dari para stakeholders. Dalam penelitian ini ada tiga tahapan dalam analisis data, yaitu :

1. Reduksi Data, yaitu data yang diambil dari transkip wawancara dan dokumen terpilih dan difokuskan pada hal-hal yang berhubungan dengan proses pertanggungjawaban keuangan Gereja.

2. Penyajian Data, yaitu data-data hasil transkip wawancara dan dokumen yang dituangkan dalam teks naratif atau kata-kata untuk menjawab rumusan masalah sehingga menghasilkan informasi yang jelas dan dapat dipahami.

3. Penarikan Kesimpulan, yaitu tahapan merumuskan makna atau memutuskan kesimpulan dari data yang telah disajikan dalam teks naratif secara menyeluruh sehingga menghasilkan informasi akhir yang lebih jelas, eksplisit dan mendasar.

\section{HASIL DAN PEMBAHASAN}

\section{Pengelolaan Keuangan Gereja}

Gereja merupakan salah satu organisasi nirlaba yang berfungsi sebagai tempat ibadah, dimana pelaksanaan fungsinya melibatkan seluruh anggota organisasi yaitu jemaat dan pengurus gereja. Pengelolaan dana dalam Gereja diperlukan metode yang efisen dan efektif sehingga dalam pengelolaan tersebut dapat dipertanggungjawabkan sehingga jemaat dapat mempercayai pihak Gereja dalam mengelola persembahan yang telah diberikannya kepada Tuhan.

\section{Pengertian Akuntabilitas Keuangan}

Berdasarkan hasil wawancara dan observasi, pendeta Gereja Toraja Jemaat Tallunglipu mendefenisikan akuntabilitas keuangan adalah tanggungjawab yang harus dilakukan secara jujur dan benar kepada Tuhan maupun kepada warga jemaat. Seperti yang disampaikan Pdt.John Adi Palimbong, S.Th sebagai berikut :

" persembahan merupakan tanda ungkapan syukur warga jemaat kepada Tuhan karena itu sistem kejujuran, kebenaran, dan rasa penuh tanggungjawab dalam mengelolanya itu harus kepada Tuhan dan kemudian kepada warga jemaat untuk mempertanggungjawabkan keuangan tersebut secara tertulis."

Dan kemudian akuntabilitas keuangan yang diperkuat oleh bendahara Gereja adalah bentuk pertanggungjawaban yang transparan, selain itu didasari takut akan Tuhan dalam mengelola keuangan Gereja Seperti yang disampaikan bendahara Gereja yaitu Dkn. Hendrik Tapparan sebagai berikut:

" pertanggungjawaban yang selama ini kita lakukan baik kepada warga jemaat maupun kepada Tuhan itu sudah sangat diusahakan transparan dan dikelola sejujur-jujurnya dan tentunya didasari takut akan Tuhan sehingga menghindari pikiran-pikiran negatif dari warga jemaat."

Pernyataan diatas juga menjelaskan bahwa persembahan yang jemaat berikan kepada Tuhan dikelola oleh pihak Gereja sebaik mungkin dengan pernuh rasa tanggungjawab untuk keperluan Gereja dan bukan untuk keperluan pribadi maka dari itu pertanggungjawaban akan pemasukan dan pengeluarannya pun transparan kepada jemaat untuk menghindarkan jemaat dari pikiran negatif tersebut.

\section{Bentuk Akuntabilitas Keuangan}

Bentuk akuntabilitas keuangan yang dilakukan dalam Gereja Toraja Jemaat Tallunglipu yaitu dengan pencatatan laporan keuangan yang transparan dan jujur dari uang 
masuk hingga penggunaanya. Seperti yang disampaikan Pdt. John Adi Palimbong, S.Th sebagai berikut:

"ya, kita berusaha untuk kemudian semua keuangan transparan dilaporkan, akuntabilitasnya bisa dipertanggungjawabkan dan karena itu memang pencatatannya sangat diusahakan transparan mulai dari uang masuk lalu kemudian dilaporkan kepada bendahara, dan kemudian ketika komisi dalam jemaat menggunakan maupun organisasi intra gerejawi menggunakannya senantiasa tentunya ada rasa tanggungjawab yang melebihi tanggungjawab secara tertulis yaitu tanggungjawab kepada Tuhan."

Transparansi adalah nilai utama dari akuntabilitas, karena transparansi adalah wujud dari keterbukaan agen kepada prinsipalnya. Hal ini diperkuat oleh salah satu warga jemaat yaitu Ibu Erny Pongmassangka :

"ya, menurut saya pelaporan yang dilaksanakan di Gereja Toraja Jemaat Tallunglipu sudah transparan dan jelas dikarenakan pelaporannya juga sudah setiap bulan yah, dan ini juga semuanya sepertinya sudah tertera langsung di warta jemaat baik itu penerimaan maupun pengeluarannya jadi sistemnya mudah dipahami dan kita bisa ketahui uang yang kami persembahkan ke Gereja dipakai untuk keperluan apa saja."

Hal ini kemudian jelas dipahami bahwa konsep transparansi yang dilakukan oleh pihak agen merupakan bentuk akuntabilitas kepada pihak principal dalam artian segala bentuk informasi pengelolaan keuangan Gereja yang dilakukan oleh pihak Gereja tentu semuanya itu dipertanggungjawabkan kembali kepada warga jemaat sehingga laporan keuangan yang tercantum dalam warta jemaat merupakan bentuk akuntabilitas keuangan kepada jemaat. Hal ini diperkuat oleh pernyataan bendahara Gereja yaitu Dkn. Hendrik Tapparan sebagai berikut:

"dalam urusan keuangan cara untuk mempertanggungjawabkannya ke jemaat tentunya dengan memberikan laporan keuangan yang sudah tercantum dalam warta jemaat. Jadi semua persembahan, donatur(pemberi sumbangan), dll sudah tercantum didalamnya baik itu penerimaan maupun pengeluaran setiap bulan."

Dengan itu persembahan yang telah diberikan oleh warga jemaat kepada Tuhan itu merupakan tanggungjawab pihak Gereja dalam mengelolanya untuk kebutuhan Gereja dan segala bentuk pertanggungjawaban pelaporan keuangan kepada jemaat sudah tertera dalam warta jemaat, jadi jemaat bisa memantau persembahan yang dimasukkannya.

Berdasarkan dari ketiga pernyataan tersebut kepercayaan menjadi hal yang sangat diutamakan dalam praktik pertanggungjawaban keuangan Gereja Toraja Jemaat Tallunglipu karena jemaat mengharapkan persembahan yang diberikan kepada Tuhan sebagai wujud ungkapan syukur, maka dari itu penggunaan dan pengelolaannya pun harus transparan demi membangun rasa kepercayaan antara agen dan prinsipal. Persembahan yang tentunya diberikan kepada Tuhan salah satunya adalah perpuluhan karena persembahan dalam wujud perpuluhan yang diberikan kepada Tuhan artinya bahwa kita sudah mempersembahkan diri kita sendiri kepada Tuhan dan ditetapkan sebagai pertanda fisik dan duniawi dari komitmen manusia kepada-Nya (Jian, 2001) seperti yang dikatakan oleh Ibu Erny Pongmassangka :

"tanggungjawab kami kepada Tuhan selaku warga jemaat yaitu salah satunya dengan memberikan persembahan sebagai tanda ungkapan syukur kami kepada Tuhan atas berkat yang dikaruniakannya. Seperti ada perpuluhan dimana Allah memerintahkan kepada kita untuk mengembalikan kepada-Nya apa yang pertama-pertama telah diberikan-Nya kepada kita maka dari itu tugas kita adalah mengkangkat perpuluhan lalu membawanya ke Gereja merupakan tanggungjawab kita kepada-Nya."

Berdasarkan pernyataan tersebut maka dapat diidentifikasi bahwa jemaat di Gereja Toraja Jemaat Tallunglipu telah menyadari dan mengakui bahwa segalanya berasal dari Tuhan dan semua pada dirinya adalah milik Tuhan. Kita hanya sebagai pengelola-Nya.

Berdasarkan laporan keuangan organisasi nirlaba sesuai dengan PSAK No.45 terdiri dari laporan arus kak, laporan aktivitas, laporan posisi keuangan dan catatan atas laporan keuangan. Pada saat temuan hasil dokumentasi, laporan keuangan Gereja Toraja Jemaat Tallunglipu belum sesuai dengan PSAK No.45. Laporan keuangan yang dibuat hanya 
berupa laporan bulanan dan tahunan. Berdasarkan temuan tersebut peneliti melakukan konfirmasi kepada Bendahara Gereja mengenai penyebab Gereja Toraja Jemaat Tallunglipu tidak menyusun laporan keuangan sesuai dengan PSAK No,45. Beliau mengungkapkan bahwa:

"laporan yang kami buat hanya berupa laporan bulanan dan tahunan. Karena mungkin jika membuat laporan seperti itu agak rumit dan juga harus disosialisasikan terlebih dahulu ke dalam sidang majelis Gereja. Jadi saat ini digereja kami hanya memakai sistem yang cukup sederhana yang tentunya tidak perrlu diganti dengan yang baru lagi karena sistem ini lebih mudah untuk dipertanggungjawabkan. "

Penjelasan yang diungkapkan oleh Bendahara Gereja dapat disimpulkan bahwa Gereja Toraja Jemaat Tallunglipu tidak membuat laporan keuangan sesuai dengan PSAK No.45 karena dianggap bukan sistem yang mudah jadi terlebih dahulu disosialisasikan ke dalam sidang majelis gereja karena laporan keuangan gereja yang sederhana dirasa sudah cukup untuk dapat dipertanggungjawabkan dan tidak perlu diganti dengan sistem baru.

\section{Bentuk Akuntabilitas Transendental}

Salah satu bentuk akuntabilitas pelaporan yang digunakan yaitu perencanaan dan pelaksanaan suatu kegiatan. Di Gereja Toraja Jemaat Tallunglipu seluruh kegiatan dan aktivitas yang dilakukan seperti kegiatan retret, kegiatan natal dan tahun baru, kegiatan paskah, dan kegiatan-kegiatan lain diluar gereja semuanya merupakan bentuk tanggungjawab pengurus Gereja yang harus dilaksanakan dan dilaporkan karena ini sudah merupakan tugas yang diwajibkan dalam pemenuhan pelayanan. Seperti yang dikatakan oleh Pnt.Katrina Nety P :

"kami selaku majelis Gereja mempertanggungjawabkan segala kegiatan/aktivitas kami dalam sidang majelis Gereja yang diadakan selama $2 x$ setahun jadi seluruh program kerja yang terealisasi maupun tidak terealisasi harus dipertanggungjawabkan masing-masing majelis Gereja."

Umumnya majelis Gereja melaporkan segala bentuk tanggungjawab yang telah diberikan selama menjadi majelis Gereja dalam sidang Majelis Gereja, jadi adapun kegiatan yang tidak terealisasi akan dievaluasi bersama dalam sidang tersebut demi mendapatkan hasil yang diinginkan.

Pelayananan yang juga dilakukan seperti kebaktian-kebaktian rutin kunjungan kerohanian juga dilaksanakan di Gereja Toraja Jemaat Tallunglipu seperti hasil wawancara dengan Pdt. John Adi Palimbong, S.Th :

"dalam segi pelayanan sesuai dengan visi dan misi Gereja Toraja berarti kita diajar untuk menjadi berkat bagi orang lain artinya tugas kita didunia untuk melayani sesama dalam keadaan suka maupun duka yang merupakan salah satu bentuk pertanggungjawaban kami juga kepada Tuhan."

Pemaknaan akuntabilitas transendental ini merupakan kegiatan/aktivitas yang dilakukan oleh pihak Gereja untuk memenuhi tugasnya didunia untuk melayani sesamanya. Bahkan, ini merupakan bentuk pertanggungjawaban pihak Gereja kepada Tuhan akan tugas yang diberikan dari-Nya dengan penuh sukacita. Stewardship theory memandang bahwa manajemen organisasi itu sebagai "stewardship/pelayan", yang akan bertindak dengan penuh kesadaran, arif dan bijaksana bagi kepentingan organisasi. Selain itu, teori ini juga menggunakan pendekatan governance yaitu menghasilkan informasi laporan pertanggungjawaban yang berkualitas.

Gereja sebagai suatu organisasi yang dapat dipercaya melaksanakan tugas dan fungsinya dengan tepat, membuat pertanggungjawaban yang diamanahkan jemaat kepadanya, sehingga ada damai sejahtera ketika Gereja menjalankan pelayanannya kepada Tuhan. Seperti wawancara yang diperkuat oleh Pnt.Katrina Nety P. mengatakan bahwa :

" dalam hal melayani sesama kami selaku majelis Gereja juga turun tangan membantu pendeta untuk melayani warga jemaat yang membutuhkan pelayanan karena berbagai krisis kehidupan. Jadi menurut saya ini merupakan salah satu bentuk pertanggungjawaban kami 
kepada Tuhan karena tugas kerohanian ini merupakan panggilan juga sebagai wakil Tuhan dalam gereja yang harus kami laksanakan sebagai Majelis Gereja”.

Majelis Gereja merupakan rekan pendeta dalam memelihara, melayani, memimpin dan menjalankan disiplin gerejawi berdasarkan firman Tuhan. Jadi tugas melayani warga jemaat yang diberikan kepada majelis Gereja diyakini merupakan bentuk akuntabilitas kepada Tuhan dalam memberitakan Injil.

Selain pendeta dan majelis Gereja, jemaat juga tentunya mempunyai tanggungjawab kepada Tuhan seperti yang dikatakan Ibu Erny:

" pastinya bentuk pertanggungjawaban kami kepada Tuhan selaku warga jemaat di Gereja Toraja Jemaat Tallunglipu itu adalah beribadah setiap hari Minggu, beribadah di setiap Ibadah Rumah Tangga dll. Dan kami juga selalu siap membantu pendeta maupun majelis Gereja yang butuh pertolongan untuk sesama kami."

Sehingga akuntabilitas di Gereja Toraja Jemaat Tallunglipu bukan hanya tentang keuangan melainkan melayani sesame juga merupakan tanggungjawab kita kepada Tuhan karena kita diutus kedalam dunia ini hanya untuk sementara sehingga hidup kita harus bermakna dihadapan-Nya.

\section{Bentuk Akuntabilitas Horizontal}

Selain bentuk pertanggungjawaban Gereja kepada jemaatnya melalui laporan keuangan yang transparan dalam bentuk warta jemaat, pihak Gereja juga punya tanggungjawab yang luar biasa kepada jemaatnya dalam bentuk diakonia. Di Gereja Toraja Jemaat Tallunglipu program diakonia yang di lakukan ada 2 macam yaitu diakonia karitatif dan diakonia transformatif. Dalam diakonia karitatif diadakan kegiatan dalam bentuk mendata anggota jemaat yang tidak mampu dan perlu dibantu dari tiap-tiap kelompok dan tentunya akan ada pendistribusian bantuan materil diakonia setiap minggu pertama tiap bulan dan ada juga kunjungan warga jemaat yang sakit maupun bantuan yang diberikan kepada warga jemaat yang mengalami bencana dan yang sedang berduka. Dan tidak hanya itu di Gereja Toraja Jemaat Tallunglipu juga mengadakan posyandu lansia yaitu membantu para orangtua yang sudah lanjut usia beserta pelayanan anak cacat atau gangguan kesehatan permanen (disabilitas) yang dilakukan oleh diaken di tiap kelompok masingmasing. Dan yang berikutnya adalah diakonia transformatif dimana program ini memberikan pengembangan kepada yayasan Gereja Toraja Jemaat Tallunglipu yaitu TK Siangkaran Tallunglipu yang tepatnya berada dihalaman Gereja Toraja Jemaat Tallunglipu dalam bentuk mengupayakan dana untuk perkembangan dan kemajuan TK Siangkaran ini dan juga pihak Gereja melalui diaken memberikan bantuan pendidikan dalam bentuk beasiswa untuk anakanak yang mempunyai ekonomi lemah(kurang mampu). Perwujudan akuntabilitas horizontal ini atas pengelolaan keuangan dari Gereja Toraja Jemaat Tallunglipu yang ditujukan kepada umat, yang merupakan stakeholder dari Gereja Toraja Jemaat Tallunglipu karena pendanaan semua aktivitas operasional berasal dari persembahan umat, dan juga semua aktivitas gereja tersebut juga digunakan untuk pelayanan bagi warga jemaat.

\section{SIMPULAN}

Berdasarkan hasil penelitian yang telah dilakukan mengenai praktik akuntabilitas dalam organisasi Gereja Toraja Jemaat Tallunglipu, maka dapat diambil kesimpulan sebagai berikut :

1. Akuntabilitas keuangan dimaknai dalam bentuk pertanggungjawaban pihak Gereja kepada jemaatnya dengan pencatatan laporan keuangan yang transparan yang tersedia dalam bentuk warta jemaat demi membangun rasa kepercayaan antara agen dan prinsipal sehingga persembahan yang diberikan jemaat kepada Tuhan sebagai wujud ungkapan syukurnya digunakan dan dikelola sebaik mungkin untuk keperluan Gereja. Dan dengan mengelola keuangan Gereja dengan jujur dan penuh rasa tanggungjawab juga merupakan pertanggungjawaban pihak Gereja kepada Tuhan karena diberikan kepercayaan untuk mengelola keuangan tersebut. 
2. Akuntabilitas Transendental atau pertanggungjawaban kerohanian dimaknai dalam bentuk kegiatan/aktivitas yang dilakukan oleh pihak Gereja dalam memenuhi tugas pelayanannya salah satunya untuk melayani sesama, sehingga majelis Gereja meyakini bahwa tugas melayani warga jemaat ini merupakan bentuk akuntabilitas kepada Tuhan dalam memberitakan Injil. Karena melayani sesama yang membutuhkan bantuan juga merupakan tanggungjawab pihak Gereja sebagai orang yang diutus Tuhan ke dalam dunia untuk sementara sehingga hidup ini harus bermakna dihadapan-Nya.

3. Akuntabilitas Horizontal dimaknai sebagai bentuk pertanggungjawaban pihak Gereja yang luar biasa kepada jemaatnya dalam bentuk diakonia. Di Gereja Toraja Jemaat Tallunglipu program diakonia yang di lakukan ada 2 macam yaitu diakonia karitatif dan diakonia transformatif. Diakonia karitatif merupakan dukungan dan bantuan materil kepada warga jemaat yang kurang mampu, sakit, yang mengalami musibah bencana dan yang sedang dalam kedukaan, pelayanan posyandu lansia dan pelayanan bagi anakanak yang mengalami disabilitas. Sedangkan diakonia transformatif merupakan program kepada yayasan Gereja Toraja Jemaat Tallunglipu yaitu TK Siangkaran Tallunglipu dalam bentuk mengupayakan dana untuk perkembangan dan kemajuan TK Siangkaran dan juga pihak Gereja melalui diaken memberikan bantuan pendidikan dalam bentuk beasiswa untuk anak-anak yang mempunyai ekonomi lemah(kurang mampu). Sehingga akuntabilitas horizontal ini dilakukan pihak Gereja untuk membantu warga jemaat yang membutuhkan.

4. Wujud akuntabilitas keuangan dalam pelaksanaan akuntabilitas transendetal dan akuntabilitas horizontal dinyatakan dalam alokasi anggaran yang mempunyai presentasi $30 \%$ untuk transendental, $20 \%$ untuk horizontal dan 50\% untuk operasional umum.

Berdasarkan hasil penelitian dan kesimpulan yang ada, maka saran dari penulis yaitu agar ada unsur penerimaan dana yang mengikat jemaat dengan pelaksanaan 3 bentuk akuntabilitas tersebut dan mengharapkan kepada jemaat dan pihak Gereja untuk saling mendukung bersama program yang telah direncanakan agar tercipta kepercayaan antara pihak pemberi amanah dan pihak yang menjalankan amanah tersebut sehingga pihak pengelola pun bisa mempertanggungjawabkan tugas yang dipercayakan kepadanya di hadapan Tuhan maupun di hadapan jemaat. Dan untuk penelitian selanjutnya diharapkan dapat mengembangkan penelitian ini dengan lebih luas dan juga ada baiknya jika PSAK Nomor 45 Tahun 2011 juga digunakan sebagai pedoman pelaporan keuangan Gereja Toraja Jemaat Tallunglipu dengan tujuan supaya meningkatkan akuntabilitas Gereja kepada publik terkait pengelolaan keuangan dan harta benda Gereja, dan untuk membentuk keseragaman bentuk pelaporan keuangan dengan gereja-gereja lainnya yang berada dalam wilayah Indonesia.

\section{REFERENSI}

Dewi, AT Atmaja, IMP Adiputra, M. Si. (2015). Konsep Akuntablititas Keuangan Dalam Organisasi Keagamaan. JIMAT (Jurnal IImiah Mahasiswa Akuntansi S1), Volume 3, Nomor 1 .

Gray R.,C. Day, D.Owen, R. Evans and S. Zadek. 1997. Struggling With the Praxis of Social Accounting; Stakeholder, Accountability, Audit, and Procedurs, Accounting, Auditing, and Accountability Journal Vol 17 no.4 pp 543-577

Gray, R., Jan B., et al (2006) and C. David. 2006. NGOs, Civil Society and Accountability:Making the People Accountable to Capital, Accounting, Auditing, and Accountability JournaNol.19, No.31. Pp 319-348.

Jacobs K. and S. Walker. (2000). Accounting and Accountability in the INOA Community . Jasmin dan Luther (2010). Transparansi dan Akuntabilitas Keuangan GBKP. Jurnal GBKP. Jensen, M.C. and W.H. Mackling. (1976). Teory of the Firm : Managerial Behaviour, Agency Cost and Ownership Structure. Journal of Financial Economics, October, Vol. 3, No.4 pp 305-360. 
Jian, W. 2001. Persembahan Yang Baik \& Benar. Yayasan Kalam Hidup. Bandung

Lembaga Alkitab Indonesia. 2014. Alkitab Terjemahan Baru. Jakarta

Mardiasmo. (2004). Membangun Akuntabilitas Publik Keuangan Negara. Yogyakarta: Media Akuntansi.

Mardiasmo. (2009). Akuntansi Sektor Publik. Yogyakarta: Andi.

Paranoan, N \& C. Totanan. 2016. Akuntabilitas Berbasis Karma. Disajikan dalam Pertemuan Masyarakat Akuntansi Multiparadigma Nasional (TEMAN 4), Universitas Mercu Buana, Jakarta, 14-15 April 2016.

PSAK No.45 Tentang Pelaporan Keuangan Organisasi Nirlaba. 2011. Jakarta : Ikatan Akuntan Indonesia.

Randa F. (2010). Akuntabilitas Kepemimpinan Dalam Organisasi Keagamaan (Studi Etnografi pada Gereja Katolik di Tana Toraja ). Jurnal Simak Vol 8 No.2.

Randa F. (2011). Akuntabilitas Keuangan Dalam Organisasi Keagamaan ( Studi Etnografi pada Sebuah Gereja Katolik di Tana Toraja ). Jurnal SIMAK Vol 9 No. 2 Oktober , 59.

Randa, F. (2011). Rekonstruksi Konsep Akuntabilitas Organisasi Gereja. SNA 14, Aceh .

Simanjuntak, Dahnil, Anzar, (2011) , Akuntabilitas Dan Pengelolaan Keuangan Di Masjid, Simposium Nasional Akuntansi XIV Aceh 2011.

Sinclair, A. (1995). The Chamelon of Accountability; Forms and Discources. Accounting, Organization, and Society , Pp 219-237. 